\title{
REFLEXIONES SOBRE LA FIGURA DEL MONSTRUO
}

\author{
Helena Tur Planells \\ I.E.S. Joan Maria Thomàs \\ (Palma de Mallorca)
}

El monstruo es una figura que aparece en todas las culturas y, en consecuencia, en numerosas obras literarias o de la tradición oral. 'Monstruo' es un término que cubre muchas significaciones, que pueden ir desde la amplitud de lo extraño (y lo extranjero), simbolizar lo malvado o concretarse en un ser extraordinario y fucra de lo normal. Pero, sin duda alguna, la idea de monstruo implica una oposición. El monstruo es, de alguna manera, algo que se aleja de la idea de normalidad, es lo diferente. La diferencia remite a una identidad, algo es diferente respecto a algo, y esta diferencia suele tener las connotaciones de la amenaza. Ceserani argumenta: «La escena de la aparición repentina e inesperada de un extraño en el espacio doméstico es casi un estereotipo, presente ya en la psicología y en el imaginario cultural de las comunidades humanas antes aún que en los textos literarios, artísticos o cinematográficos, profundamente implicado en los procesos de construcción de la identidad de los pueblos, de las comunidades étnicas y de las naciones»'. La aparición inesperada de un extraño no sólo produce un rechazo, sino que primero suscita una inquietud y una turbación porque es alguien que desconocemos (y esta ignorancia se convierte en metonimia de todo lo extraño, de todo aquello que permanece oculto para nosotros porque nuestro sistema epistemológico aún no lo ha clasificado). Lo desconocido es una amenaza precisamente por desconocido. Ignoramos qué viene con él, de qué es portador porque, como afirma Albiac: «el extranjero es siempre portador virtual de peste» ${ }^{2}$. El monstruo es, entonces, un elemento directamente relacionado con el reconocimiento, con la integración, con la comprensión, pero de todos ellos participa negativamente. En el monstruo hay un yo negado, repudiado. El patito feo es un monstruo para una familia de patos que no lo reconoce como miembro y se despreocupa por comprenderlo. Este repudio convierte al monstruo en mártir que huye de las miradas que lo

1.- Ceserani, R., Lo fantástico, Visor, Madrid, 1999, p. 123.

2.- Albiac, G., Ia muerte. Metáforas, mitologías y símbolos, Paidós, Barcelona, 1996, p. 70. 


\section{REFLEXIONES SOBRE LA FIGURA DEL MONSTRUO}

rechazan y de la incomprensión. El monstruo lleva en sí el carácter delictivo porque su presencia amenaza a una comunidad, su diferencia es turbadora de una identidad. El monstruo carece de dignidad, porque la dignidad necesita el reconocimiento. Safranski reflexiona sobre ello: «Todos los hombres han nacido libres e iguales en dignidad y derechos, proclama el artículo primero de la Declaración de Derechos Humanos. Pero, de hecho, ¿nace el hombre dotado de dignidad tal como nace dotado de miembros corporales? Es evidente que no. La dignidad es reconocida, pero ¿qué instancia la reconoce? Hoy decimos que esta instancia es la sociedad ${ }^{3}$.

El monstruo, ser indigno, amenazador, supone un peligro para la comunidad y responde a un algo asocial, se convierte en algo malo que hay que apartar. Rousseau identificaba lo asocial al mal, y decía que debía ser eliminado. En este sentido, el término 'monstruo' es un deíctico que se actualiza en función del orden establecido. La aparición del monstruo implica una ruptura en la estructuración de una sociedad, en los esquemas y el orden social. Pero la ruptura, la trasgresión, suponen un algo instituido de antemano, y en este sentido, nos planteamos la pregunta que se hacía San Pablo sobre si hay pecado por causa de la ley o si hay ley por causa del pecado. Si en lugar de Dios hablamos de la sociedad, vemos que la ley engendra el delito; la norma, lo diferente; la seguridad, la amenaza. El orden social es también un orden relativo (aunque en muchos momentos sea tomado como absoluto), un orden histórico y determinado a un momento y lugar, a una identidad. Pero la identidad es dinámica, y es precisamente "lo otro" (la relación) lo que la construye. En la época clásica, los marinos griegos que desembarcaban en islas eran reconocidos como otro yo porque ellos también reconocían en la comunidad insular una identidad. La hospitalidad que cantan los poetas responde a un reconocimiento entre dos yoes. Se trata del espíritu opuesto al caso del monstruo, donde el otro yo es una amenaza para la propia identidad y no merece hospitalidad, sino rechazo. El rechazo se da desde un lugar porque ese lugar no quicre ser cuestionado; el monstruo no merece dignidad porque la identidad que lo repudia se siente insegura, se sabe instituida, no eterna. La "identidad" siente su fragmentación ante la visión del monstruo, tal como ocurre con el desdoblamiento y la fragmentación. Porque la figura del monstruo siempre trae a colación la otredad, al otro yo y la dignidad de este otro yo, al rostro del que hablan Lévinas o Buber. La identidad no está fijada y es un continuo hacerse, es un hacerse-con, porque el hombre es apertura y relación. El monstruo es la amenaza de lo fijado, lleva en sí la conciencia de que el hombre es también los otros, tambalea los fundamentos de un yo delimitado, de una sociedad endogámica. La reacción de la sociedad es la de no reconocer la dignidad del otro. Afirma Clement Rosset que el reconocimiento históricamente se otorga a través de un documento, un "modelo" manifestado por quien representa a la sociedad: «Lo que garantiza la identidad es y ha sido siempre un acta pública, una partida de nacimiento, un documento de identidad, los testimonios concordantes de la portera y los vecinos» ${ }^{4}$. Pero este orden social crea monstruos dentro de su propia sociedad, no es necesaria la figura del extranjero para la aparición del monstruo, cualquier marginal, enfermo, inútil, loco, delincuente o trasgresor moral es un monstruo. En Los miserables, de Víctor Hugo, Jean Valjean participa del carácter monstruoso porque su nombre no consta en el Registro Civil. Valjean evita identificarse y siempre resulta sospechoso. En el film, producido y dirigido por Andrev Niccol en 1997, titulado Gattaca (un experimento genético), el reconocimiento se da gracias a la genética. La fe en la Ciencia es Ilevada al punto de servir de fundamento a la valoración moral. El reconocimiento se da a través del estudio de los genes, y así, si el estudio genético indica que tal persona gozará de buena salud y fortaleza física favorable para la sociedad, es considerada válida; de lo contrario, es no válida. Por ello, hay dos tipos de hombres: los engendrados naturalmente, que permiten la introducción del azar en el momento de su concepción, y los engendrados tras la selección del "mejor" óvulo de la madre y el "mejor" espermatozoide del padre para determinar las características (saludables, pero también estéticas) del futuro nato. Se trata de un largometraje futurista donde el clasismo deriva de la genética.

3.- Safranski, R., El mal o el drama de la libertad, Tusquets, Barcelona, 2002, p. 245.

4.- Rosset, C., Lo real y su doble, Tusquets, Barcelona, 1993, p. 105. 


\section{HELENA TUR PLANELLS}

Igualmente deriva de la genética el panóptico, pues el control de cualquier partícula humana, que deja el hombre a modo de rastro en su cotidianidad, es analizado continuamente a través de máquinas al acceso de todos. El control del gen recuerda al nombre de Valjean (o a su anonimato) y cuya sombra se personifica en la figura de Javert. En Gattaca, los no válidos son los que perjudican a la sociedad porque su "utilidad" es menor y, por tanto, son un escollo en la humanidad destinado a ser superado, condenado a desaparecer (como los salvajes en Un mundo feliz). Aquí, la validez está muy ligada a la potencialidad enfermiza, y es que monstruo y enfermo también son dos elementos que se entrelazan en numerosas ocasiones, como vercmos a continuación. Es cierto que el rasgo enfermizo también es propio del vampiro, que es un monstruo ctónico y demoníaco, una amenaza para el viviente, pero, ¿no es la enfermedad un término que se opone a la salud? ¿No es enfermizo todo lo no saludable? ¿Quién delimita salud/enfermedad, sobre todo en un caso tan delicado como el de la locura? Gadamer dice que «nos encontramos ante una pregunta sin respuesta: ¿qué es la salud? Se sabe, más o menos qué son las enfermedades. Estas poseen, por así decirlo, el carácter rebelde de la excepción" ${ }^{5}$. Y Thomas Sawtz afirma que las enfermedades psicológicas existen desde que existen psicólogos. El término excepción, de nuevo, es relativo al de normalidad, a lo instituido como normal, desde la norma o la moral. La enfermedad, así entendida, es también transgresora. La imagen enfermiza es la imagen de un cuerpo no sano, pero de un cuerpo, y es que el reconocimiento está muy vinculado a la imagen del cuerpo, a la apariencia. García Cortés hace referencia a ello: «Se podría hablar de un caos, una lucha en este mundo caótico, lleno de referencias horribles a la inseguridad física del individuo y el cuestionamiento de su identidad ${ }^{6}$. Hoy en día, en una sociedad marcada por el canon estético de la delgadez, el gordo es un monstruo. Bourdieu habla de la necesidad de «contextualización del cuerpo, de su integración en un entorno social»? El cuerpo, entonces, se convierte en metáfora del espíritu, y esta identificación tiene su fundamento, según Remo Ceserani en la creencia de que: «La trasgresión de un individuo tiene su castigo y su efecto en el cuerpo sano, del mismo modo en que la sífilis era la consecuencia de los actos licenciosos del individuo" ${ }^{8}$. En El retrato de Dorian Gray, de Wilde, el personaje mantiene su apariencia impoluta a pesar de su carácter moral, pero no así la imagen de su retrato, que refleja en su fealdad todo el horror de su conducta. Monstruo, delincuente, enfermo, inmoral o asocial son conceptos que van, así, muy unidos a la deformidad. La deformidad, la imagen que no responde a la idea de normalidad, o a la forma reconocida, recibe el rechazo social porque supone una deformidad del espíritu. "Enfermo" está Peter Schlehmil porque no tiene sombra (la he vendido al diablo) y "enfermo" está Drácula porque su imagen no se refleja en el espejo. La deformidad y la enfermedad del cuerpo son indicio de la deformidad y la enfermedad del alma. Susan Sontag habla de la influencia de la enfermedad en el ámbito social: «...la enfermedad y sus consecuencias sociales, estéticas e incluso morales. La enfermedad puede adquirir un valor estético como ocurre en el caso de la tuberculosis en el periodo Romántico. Pero otras enfermedades, como el sida o el cáncer, en su fase degenerativa, distorsionan el cuerpo de una manera mucho más desfigurativa y descompositiva, convirtiendo el cuerpo en algo oscuro que pierde su belleza y adquiere un carácter de enfermedad degenerativa también en el ámbito social»?. Dorian Gray logra la aceptación de la comunidad gracias a su imagen "pura", pero cuando él mismo se reconoce en el cuadro y descubre la imagen de su alma, con todos los vicios y delitos grabados en ella, sabe que está ante una imagen repulsiva que debe ocultar. Igual ocurre en El extraño caso del doctor Jeckyll y míster Hyde, de Stevenson: Hyde, que es la imagen deforme y monstruosa del cuerpo del Dr. Jeckyll, es la parte siniestra del alma del médico, imagen fea y terrible como la maldad. Jeckyll, en su confesión, escribe: «Era algo humano y natural. Tenía ante

5.- Gadamer, H. G., El estado oculto de la salud, Gedisa, Barcelona, 1996, p. 113.

6.- García Cortés, J. M., Orden y Caos, Anagrama, Barcelona, 1997, p. 169.

7.- Bourdieu, P., "Notas provisionales sobre la percepción del cuerpo"en Materiales de la sociología crítica, La Piqueta, Madrid, 1986, p. 87.

8.- Ceserani, R., Lo fantástico, cit., p. 23.

9.- Sontag, S., La enfermedad y sus metáforas y el sida y sus metáforas, Taurus, Madrid, 1996, p. 123. 


\section{REFLEXIONES SOBRE LA FIGURA DEL MONSTRUO}

mis ojos una imagen real del espíritu, imperfecta y dividida que, por costumbre, llamaba mía» ${ }^{10}$. Pero si viéramos lo extraño desde el punto de vista de Hyde, la imagen horrible y malvada sería la de Jeckyll. La fealdad del cuerpo se determina porque existe un canon de belleza. Pero si el cuerpo feo simboliza lo malo, también a través del cuerpo puede redimirse (purificarse) esa maldad. Éste es el sentido del suplicio. Foucault habla de la relación entre alma y cuerpo en la materialización del suplicio como consecuencia penal de delito. En Vigilar y castigar ${ }^{11}$ muestra la idea de proporción entre el tipo y duración del suplicio aplicado al reo y el delito del que es acusado. Aquí, el suplicio responde a un modo de purificar el alma (a través del cuerpo) para poder ser acogido por Dios cuando muera. Se trata de desmonstrualizar al culpable. Aunque la condena sea a muerte, el reo debe presentarse ante ella purificado.

El monstruo del Dr. Frankenstein, resulta un ser repugnante por su deformidad, por la cualidad extraordinaria de un cuerpo que está conformado con amputaciones de otros cuerpos. Antes de cometer ningún crimen, el monstruo de Shelley ya es considerado un criminal, no sólo por la sociedad, sino por su propio creador: «Me quedé inmóvil, mirándolo fijamente: no había duda. Un relámpago lo iluminó y me descubrió sus rasgos con claridad. La gigantesca estatua y su aspecto deformado, más horrendo que nada de lo que existe en la humanidad, me demostraron de inmediato que era el engendro, el repulsivo demonio al que había dotado de vida» ${ }^{12}$. Pero este rechazo se convierte en un sentimiento de soledad y sufrimiento para el monstruo. El monstruo del Dr. Frankenstein lo siente así: «Todos los hombres odian a los desgraciados. ¡Cuánto, pues, se me debe odiar a mí, que soy el más infeliz de los seres vivientes! Sin embargo, vos, creador mío, me detestáis y me despreciáis, a mí, vuestra criatura, a quien estáis unido por los lazos que sólo la aniquilación de uno de nosotros romperá» ${ }^{13}$.

El monstruo de Frankenstein nos produce terror y ternura. Sin embargo, Bergson nos recuerda que la deformidad puede ser cómica: «Toda deformidad susceptible de imitación por parte de una persona bien conformada puede llegar a ser cómica» ${ }^{14}$. Esta dualidad de sensaciones que el monstruo puede producir (en apariencia opuestas) es debido a que los elementos que motivan el miedo son los mismos que motivan la risa. La diferencia está en su tratamiento. Pero el monstruo puede producir otra sensación: la fascinación. Al monstruo se le adora, se le venera, se le ofrecen sacrificios, como al minotauro ${ }^{15}$, como a King Kong. Al genio se le llama monstruo (Einstein o Maradona son monstruos) porque la sospecha de la superioridad atenta pone en evidencia la inseguridad del normal. Pero también se le puede parodiar: el monstruo es exhibido como mono de feria. Es algo que le ocurre a King Kong cuando lo trasladan a Nueva York. Pero, tal como dice Eugenio Barba, para que el monstruo sca exhibido como espectáculo, debe estar vencido, haber perdido su carácter de amenaza. En la película La parada de los monstruos (Freaks, Tod Browning, 1932) éstos son exhibidos en un circo ambulante de feria en feria. Pero a medida que la película se centra en los anormales, la normal, la bella, aparece como monstruo para ellos. Primero porque fascina por su belleza, pero después porque se revela su carácter frívolo y malvado.

Hay un ejemplo literario de un caso que puede ser considerado monstruoso por su peculiar "deformidad". Nos referimos a El hombre invisible, de Wells, cuyo protagonista carece de imagen y también de sombra. La obra establece un dilema entre existencia e imagen física. La imagen del cuerpo desaparece, pero no desaparece la presencia porque la acción no es ajena a él, sólo la posibilidad de mostrarsc. La existencia, además, se autorreconoce en un simple acto de pensamiento y en la constante voluntad de reafirmar esa presencia. El protagonista de esta obra

10.- Stevenson, R. L., Dr: Jeckyll y Mr Hyde, Bruguera, Barcelona, 1992, p. 85.

11.- Cfr. Foucault, M., Vigilar y castigar, Siglo XXI, Madrid, 1992.

12.- Shelley, M., Frankenstein o el nuevo Prometeo, Anaya, Madrid, 2000, p. 146.

13.- Ibidem, p. 147.

14.- Bergson, H., Tratado sobre la risa, Plaza \& Janés, Barcelona, 1956, p. 828.

15.- Cfr. Kazantzakis, N., Teseo en Obras Completas, Planeta, Barcelona, 1970. 


\section{HELENA TUR PLANELLS}

se ve obligado a vestirse totalmente para que no sea descubierta su invisibilidad, pero cuando su temor ocurre, ya es tenido por monstruo por toda la comunidad, y por tanto, como delincuente. Aunque en defensa propia, acaba asesinando a un hombre, y este hecho confirma el lastre de su imagen monstruosa.

Foucault opina que en el monstruo se combinan a la vez lo imposible y lo prohibido, hasta la concreción de esa noción de individuo peligroso, «ese monstruo banal y desdibujado del siglo XIX» ${ }^{16}$. El "hombre invisible" oculta su cuerpo desimaginado y desaparece tras la máscara de las ropas para evitar ser rechazado por los habitantes del nuevo pueblo al que llega. La máscara puede ser un nuevo modo de monstruosidad, pero también una forma de ocultarla: «Un yo que se oculta es un yo que desaparece (...). El poder de ocultar el rostro mediante la máscara abre la posibilidad de manifestaciones de un yo interno que permanece oculto. Podemos hacer aflorar aspectos que normalmente se ocultan o por miedo o por el precepto social que busca el ocultamiento de todo aquello que socialmente no es aceptado» ${ }^{17}$. Del mismo modo que la máscara, idénticas connotaciones puede tener el maquillaje. Maquillaje y máscara otorgan la personalidad del actor teatral, pero también hay algo de cllo en la realidad: «Maquillarse es negar nuestro yo. Ya sabemos que maquillarse supone un acto de modificación, pero que no muestra la crudeza que supone la deformación o la mutilación» ${ }^{18}$.

En este sentido, de lo otro y de lo extraño como amenaza, el monstruo (deforme, maquillado, enmascarado, no válido, no documentado) inserta una desestabilización en la sociedad. Aporta a la vez una falta de reconocimiento del monstruo, pero también un temblor en los fundamentos de la propia identidad. La pregunta qué es introduce la amenaza de dudar de quiénes somos. La conciencia de nuestro mundo ve cómo se borran sus límites. El monstruo, según García Cortés, «sería la huella de lo no dicho y no mostrado de la cultura, todo aquello que ha sido silenciado, hecho invisible. Lo monstruoso hace que salga a la luz lo que se quiere ocultar o negar» ${ }^{19}$. El monstruo aparece como una forma alegórica, designa una realidad que le es exterior, proclama la existencia de una relación entre lo que es y lo que no es, hace referencia al abismo abierto entre el mundo del Ser y de la apariencia, entre lo ideal y lo real. Lo monstruoso se presenta como un hecho extraordinario en el mundo natural. Pero también como algo extraño y desconocido de la interioridad humana. El monstruo, como el espectro, y así lo vemos en Stevenson, responde a algo propio que se muestra a modo de alteridad, pero no lo es, es mismidad que nos asusta c inquieta reconocer, pero de la que no podemos escapar porque la llevamos puesta. El monstruo es la imagen del mal como lo es el Demonio de Dios. Y el mal pertenece al drama de la libertad humana. Es el precio de la libertad porque el hombre no se reduce al nivel de la Naturaleza, sino que es el "animal no fijado", usando una expresión de Nietzsche.

El monstruo del Dr: Frankenstein participa de lo demoníaco porque adquiere el soplo vital de un modo no natural. Este monstruo no es hijo de Dios, sino del hombre, pero también de los conocimientos científicos y el uso que de ellos hace el hombre. Tambićn participa del desdoblamiento porque su cuerpo está formado por fragmentos de otros cuerpos, que a su vez son metáfora de otras identidades difuminadas y confundidas más allá de sî́ $^{20}$. El hecho de que una imagen esté compuesta por fragmentos de otras identidades no es nuevo en la idea del monstruo. Ya en Egipto encontramos la esfinge; en Grecia, el Cancerbero, la Gorgona, el sátiro, la Quimera, Giges, y muchos más. Y, por supuesto, el monstruo de Frankenstein participa de lo espectral y de

16.- Foucault, M., La vida de los hombres infames, La Piqueta, Madrid, 1990, p. 86.

17.- Ibídem, p. 215.

18.- Ibidem, p. 85.

19.- García Cortés. J. M., Orden y Caos, cit., p. 19.

20.- Castoriadis toma a Frankenstein como paradigma de la postmodernidad precisamente por su carácter fragmentado. Al mismo tiempo, recordamos que ya Nietzsche ponía en boca de Zaratustra la acusación contra sus coetáneos de no ser hombres, sino fragmentos de hombre. 


\section{REFLEXIONES SOBRE LA FIGURA DEL MONSTRUO}

la resurrección porque los fragmentos que lo configuran pertenecen a seres muertos. Sin embargo, respecto a la característica común en los seres propiamente demoníacos que es su estado de posesión, el monstruo de Frankenstein no está poseído, su conciencia es libre, y es precisamente esa conciencia la que le hace sentir la angustia de la falta de reconocimiento, la melancolía y el aislamiento del rechazo. David Lynch trata el tema del dolor del monstruo en una exposición sublime del sufrimiento en El hombre elefante (The Elephant Man, 1980).

Con la obra de Shelley, la imagen del monstruo del Dr. Frankenstein abre la idea de un proceso de deshumanización donde el cuerpo se transforma en una simple fuente de material disponible para todo tipo de manipulaciones y experimentos. Esto obliga a la sociedad moderna a tener que redefinir el concepto de muerte y, en consecuencia, el de la propia persona. Encontramos así, la construcción de la idea de que el «cuerpo humano es la condición del hombre, el lugar de su identidad, aquello que se le gaste o añada modifica su relación con el mundo de una manera más o menos visible» ${ }^{21}$. García Cortés concibe el cuerpo y su fragmentación de esta manera, recordando al mito de Frankenstein y la aparición del monstruo biológico, cuya existencia se une a la de los incapacitados, a esas personas que por accidente o nacimiento (como consecuencia de una culpa) poseen una deficiencia física y también entran en la categoría de monstruos por la supresión de sus órganos. En este punto se basa la idea de que monstruos y mutilados queden ligados por un estrecho lazo, nos dice García Cortés, y éste es un descubrimiento que han hecho los artistas que crean formas monstruosas, porque han sido atentos observadores de deformaciones y mutilaciones físicas, «obsesionados por lo ausente y lo putrefacto» ${ }^{22}$. Según cl mismo autor, son la Ciencia y la Técnica las que se encargan de remodelar y arreglar esta condición humana para poder «liberar al hombre de su relación con la carne ${ }^{23}$. La Ciencia observa los fragmentos del cuerpo, se olvida del todo y da una visión del cuerpo en sus partes, aísla éstas para ser sometidas a la técnica de transplantes y así convierte a los cuerpos en "artificiales". Es una visión reduccionista donde el cuerpo se desprestigia. La idea de estos nuevos cuerpos responde a la de unos cuerpos que han sido «despojados de su halo imaginario» ${ }^{24} \mathrm{y}$ han perdido su valor moral al ser descompuesto en sus elementos y ser reducida su visión a la suma de ellos. Lo que vemos son cuerpos cortados, separados, escindidos, de los que no quedan nada más que elementos sustituibles cuando dejan de funcionar. En 1974, el psiquiatra americano W. Gaylin publicó un artículo ${ }^{25}$ en el que sugería la creación de bancos de neomuertos, es decir, individuos en estado vegetativo criónico que permanecerían disponibles durante años para tomar muestras de órganos, sangre, piel... según necesitaran los científicos. Estos cuerpos se mantendrían con vida de modo artificial en una granja de nuevo género: el bioemporium. Michael Marshall Smith en Hermanos de carne describe una situación similar: los clones son encerrados en granjas y sirven para proveer órganos o miembros a los humanos de los que son copia. Hoy se habla de la clonación ${ }^{26}$ de seres humanos para tener repuestos en caso de que el organismo del original sufra alguna enfermedad. Se trata de una nueva panacea que, como en la alquimia, pretende "reparar" los órganos "defectuosos". Si en

21.- García Cortés, J. M, El cuerpo mutilado (La angustia de la muerte en el arte), Generalitat Valenciana, Valencia, 1996, p. 42.

22.- Ibidem, p. 43.

23.- Ibídem, p. 40.

24.- Ibidem.

25.- Gaylin, W., "Harvesting the dead", Harper's Magazine, n. ${ }^{\circ} 249$, sept. 1974.

26.- La clonación conecta directamente con el tema del gemelo (por tanto, del doble), el clon es un gemelo del original. La clonación hace innecesaria la sexualidad (la reproducción se produce a través de la copia de una célula). Además, imita a Dios (que creó a Eva a partir de una costilla de Adán), rivaliza con Dios, lo sustituye. Si a la clonación le añadimos "el sueño" de la transmisión de las experiencias del original a través de neurotransmisores colocados en su cerebro y receptores neuronales colocados en el del clon comunicados vía satélite, encontramos no sólo el desdoblamiento, sino la fragmentación de la existencia, la superación de la muerte, la insoportable vida eterna y el tema de la posesión. 


\section{HELENA TUR PLANELLS}

este pensamiento no se está cosificando al hombre, al menos se está cosificando su cuerpo, y la diferencia entre hombre y cuerpo siempre ha sido sólo un modo dicotómico de hablar de una identidad, de una única existencia. Pero ya sabemos que el tema va más allá de la intención médica, más allá de la búsqueda de salud aunque sea artificialmente, puesto que el caso de las operaciones llamadas estéticas está llegando a extremos insospechados. Las estadísticas sobre las operaciones para huir de complejos físicos son escandalosas. El cuerpo, como el vestir, responde a una moda fijada desde estereotipos que son imitados sin reflexión. Las quinceañeras sueñan con metamorfosearse en sus referentes de plástico, y los chicos de gimnasio, en sacos de hormonas. No olvidemos que todo esto corresponde a una cosmovisión superficial del cuerpo que no nace solamente en la publicidad, sino que abarca ya casi cualquier interpretación del sentido de la vida moderna. Y esto no ocurre ingenuamente, sino que responde por un lado a intereses económicos y, por otro, a intereses políticos. Conviene recordar que la alienación favorece al sistema y al Poder. Desde este punto de vista, asegura Stelarc, "ya no tiene sentido considerar el cuerpo como un receptáculo del espíritu o del vínculo social, hay que verlo más bien como una estructura por controlar y por modificar. El cuerpo no como sujeto, sino como objeto, no como objeto de deseo, sino como diseño ${ }^{27}$. Este paroxismo de la artificialidad es horroroso, pero como todo elemento horrible, también puede producirnos risa. Bergson analiza este último efecto y nos dice: «El cuerpo entonces será, para esta alma, lo que el traje era hace un instante para el cuerpo mismo, una materia inerte colocada sobre una energía viva» ${ }^{28}$.

En 1952, cuando Bernard Wolfe publica Limbo, en Hollywood ya habían comenzado las primeras operaciones de estética. Esta obra relata la aparición de una nueva sociedad donde la automutilación se convierte en razón social y moral. Los hombres (no así las mujeres) asumen como necesaria la eliminación de sus extremidades, y las amputan para sustituirlas por prótesis mecánicas. Son los llamados amps ('amputados'). "Hay distintas clases de amps, de acuerdo con el número de brazos y piernas que hayan perdido..., uniamps, biamps, triamps, tetraamps" 29 . La mutilación responde aquí a una identificación de las extremidades con la agresividad por ser consideradas éstas las articulaciones con las que se ejerce la violencia, y que ubica el instinto agresivo en su materialidad cárnica. Con su eliminación se pretende crear una sociedad pacífica, regida por la filosofía Inmov (abreviatura de inmovilización, término que usa Martine, el protagonista de la obra, y que aparece en un libro de notas en el cual había plasmado a modo de broma cl ideal de una sociedad basada en la autoamputación, una broma que años después descubre que se ha hecho realidad, que ha surgido una sociedad basada en esos textos y que lo convierte a él en un profeta). Ahora el hombre acepta voluntariamente su mutilación para poder fundirse con la máquina. El resultado que se pretende es el de una sociedad con hombres "asépticos", sin impulsos ni descargas de adrenalina: «Hemos tratado de extirpar una determinada imaginación, la memoria, el sentimiento del yo. Suprimida la mayor parte del organismo, de la sexualidad, al combatir las tensiones que emanan de la ambivalencia emocional, muchas veces destruimos, simultáneamente, la emotividad ${ }^{30}$. Al final de la obra se evidencia que la máquina no logra eliminar ese deseo destructivo del ser humano, porque la máquina deshumaniza, pero no elimina la violencia del hombre. Las prótesis, pese a todo, siguen siendo un instrumento del poder de destrucción, ya que no afectan a la potencialidad agresiva y violenta del ser humano. Limbo nos recuerda la crítica de José Sanmartín ${ }^{31}$ sobre la justificación que los científicos hacen de la experimentación genética, cuando alegan que, al descubrir el gen de la violencia, lograrán extirpar ésta de la sociedad. Sanmartín incide repetidamente en la idea de que los genes actúan por relación, rizomáticamente, y que no existe un gen de la violencia o la agresividad como no existe

27. - Stelarc, "Prosthetics, Robotic and Remote Exsitence", Leonardo 24, n. ${ }^{\circ} 5,1991$, p. 591.

28.- Bergson, H., Tratado sobre la risa, cit., p. 840.

29.- Wolf, B., Limbo, Barcelona, Minotauro, 2002, p. 43.

30.- Ibídem, pp. 66-67.

31.- Cfr. Sanmartín, J., Los Nuevos Redentores, Anthropos, Barcelona, 1992. 


\section{REFLEXIONES SOBRE LA FIGURA DEL MONSTRUO}

un gen del amor, la ternura o la concordia. Limbo también nos remite, aunque con connotaciones muy distintas, al relato de Espronceda, "La pata de palo", donde un hombre cojo se coloca una pata de palo en el lugar vacío de su pierna ausente. La pata artificial tiene vida propia y cuando el hombre empieza a andar, es ella quien dirige su camino y su velocidad. Aquí, el cuerpo y el alma no se interpretan separadamente, sino que es precisamente la inclusión de una parte de un cuerpo ajeno la que motiva la también inclusión de una voluntad impropia en la del hombre y su prótesis. Maurice Renard, en Las manos de Orlac, trata el tema de la prótesis, en este caso no artificial, sino fragmento a su vez del cadáver de un asesino. Igual que en Espronceda, las manos desobedecen a la voluntad de Orlac, están poseídas por el alma de su antiguo ser. Tienen un carácter monstruoso, demoníaco, fragmentario, espectral y vinculado a la resurrección.

Otra obra que habla del monstruo hijo de la Ciencia, como Frankenstein, es Un mundo feliz, de Huxley, donde los nuevos seres son predeterminados primero genéticamente y luego históricamente (en el sentido de que son educados a través de experiencias y conocimientos virtuales). Monstruos, para nosotros los lectores, son los alfas, betas, gammas... y, sin embargo, quien adquiere un carácter monstruoso, frente al resto de personajes, es Marx, que se sale del tipo y a veces piensa por sí mismo, y también los "salvajes" (nacidos naturalmente), agrupados en la reserva. Los monstruos genéticos participan de lo demoníaco porque están poseídos, no tienen voluntad (como el zombie), sólo apariencia de ella, y todas sus acciones y pensamientos no son más que reacciones a los estímulos que les fabrican. Son idénticos y carecen de identidad.

El tema de la identidad individual es ya puesto en cuestionamiento por Foucault al final de Las palabras y las cosas, cuando escribe que «el hombre desaparece como un rostro en la arena a la orilla del mar» ${ }^{32}$ después de analizar las relaciones de poder entre el hombre y su entorno. Pero el temor se extiende al cuerpo si pensamos en la multiplicidad de vidas que nos conforman, en todas las bacterias que poseemos o son parte de nosotros y ejercen, simbióticamente, funciones que nos resultan vitales. Si creemos, además, que cada órgano de nuestro cuerpo puede ser sustituido hasta el punto de desaparecer en esa sustitución, ¿dónde queda el yo?, ¿qué soy yo?, ¿hasta dónde soy yo?, ¿dónde "ubico" mi identidad? «El crimen perfecto sería la eliminación del mundo real»" ${ }^{33}$ nos dice Baudrillard. Tras reflexionar sobre la influencia de las nuevas tecnologías hoy en día, el autor añade: «En la actualidad, lo que sustenta la noción de "individuo" ya no es el sujeto filosófico o el sujeto crítico de la historia, es una molécula perfectamente operacional pero abandonada a sí misma y abocada a asumirse por sí misma. Carente de destino, sólo tendrá un desarrollo precodificado y se reproducirá hasta el infinito, idéntica a sí misma. La "clonación" en su aceptación más amplia forma parte del crimen perfecto ${ }^{34}$. El monstruo, aquí, cuestiona la identidad y participa de la artificialidad de lo existente, de la desnaturalización y de la inautenticidad. Estas cuestiones son llevadas al grado máximo en lo que ha venido a llamarse la "existencia virtual".

El monstruo del Dr. Frankenstein participa de los elementos y efectos de la mutilación, pero también de la existencia virtual, en el sentido que entendemos por existencia virtual lo que carece de existencia, lo que es irreal, pero que puede poseer la apariencia de vida. Baudrillard nos dice: «en su acepción habitual, lo virtual se opone a lo real, pero su repentina emergencia, al amparo de las nuevas tecnologías, ofrece la sensación de que, a partir de ahora, señala su desvanecimiento, su final» ${ }^{35}$. La virtualidad comunica directamente con el desdoblamiento, pero va más allá: la existencia virtual no sólo desdobla o prolonga la realidad, sino que la sustituye.

Los precedentes de la apariencia de la existencia desde lo que no es excluyen el mito de Adán, porque Adán recibe el soplo vital desde Dios; sin embargo, el mito del Golem ya trata de otra cosa.

32.- Foucault, M., Las palabras y las cosas, S. XXI, México, 1974, p. 215.

33.- Baudrillard, J., Contraseñas, Anagrama, Madrid, 2002, p. 65.

34.- Ibídem, p. 69.

35.- Ibídem., p. 47. 


\section{HELENA TUR PLANELLS}

Borges nos habla de esta figura, que tiene sus precedentes en el Talmud y nos remite a la obra de Gustav Meyrink, Der Golem, de 1915:

El origen de la historia remonta al siglo XVII. Según perdidas fórmulas de la cábala, un rabino construyó un hombre artificial (el llamado Golem) para que éste tañera las campanas en la sinagoga e hiciera los trabajos pesados. No era, sin embargo, un hombre como los otros y apenas lo animaba una vida sorda y vegetativa. Ésta duraba hasta la noche y debía su virtud al influjo de una inscripción mágica, que le ponían detrás de los dientes y que atraía las libres fuerzas siderales del universo. Una tarde, antes de la oración de la noche, el rabino se olvidó de sacar el sello de la boca del Golem y éste cayó en un frenesí, corrió por las callejas oscuras y destrozó a quienes se le pusieron delante. El rabino, al fin, lo atajó y rompió el sello que lo animaba. La criatura se desplomó. Sólo quedó la raquítica figura de barro, que aún hoy se muestra en la sinagoga de Praga. ${ }^{36}$

A esta narración, Borges añade: «Eleazar de Worms ha conservado la fórmula necesaria para construir un Golem. Los pormenores de la empresa abarcan veintitrés columnas en folio y exigen el conocimiento de los alfabetos de las doscientas veintiuna puertas que deben repetirse sobre cada órgano del Golem. En la frente se tatuará la palabra Emet, que significa Verdad. Para destruir la criatura, se borrará la letra inicial, porque así queda la palabra met, que significa muerte» ${ }^{37}$. Sin duda, el mito del Golem remite una vez más a la búsqueda por parte del hombre del secreto de la creación, del origen de la vida. El hombre pone a su servicio las fuerzas siderales (como en la magia negra) para lograr un "producto humano" que no deja de recordarnos a la Tecnología y la figura del androide Es una figura de la trasgresión y de la soberbia humana que se vuelve en contra del hombre como todo pacto con el diablo.

Muy comentada ha sido la figura de Olimpia en el relato de Hoffmann El hombre de arena, sobre todo por Freud y Trías para dar una interpretación de la figura del autómata. De ella, concretamente Trías alude a

[...] la duda de que un ser aparentemente animado sea en efecto viviente; $y$ a la inversa: de que un objeto sin vida esté en alguna forma animado: figuras de cera, muñecas sabias y autómatas. Así una mujer cuya belleza estribe en ese punto sutil de unión entre lo inanimado y lo animado: una belleza marmórea y frígida, como si de una estatua se tratara, pese a tratarse de una mujer viviente; un cuadro que parece tener vida. Esta ambivalencia produce en el alma un encontrado sentimiento que sugiere un vínculo profundo, intrínseco, misterioso, entre la familiaridad y belleza de un rostro y el carácter extraordinario, mágico, misterioso que esa comunidad de contradicciones produce, esa promiscuidad entre lo orgánico y lo inorgánico, entre lo humano y lo inhumano. La sensación final no deja de producir cierto efecto siniestro muy profundo que esclarece, de forma turbadora, la naturaleza de la apariencia artística, a la vez que alguna de las dimensiones más hondas del erotismo. ${ }^{38}$

Hay un ir y venir entre lo orgánico y lo inorgánico, entre lo humano y lo inhumano, entre la apariencia y el Ser que otorgan al autómata un carácter siniestro. Ceserani afirma que este efecto se origina en la frontera que oscila entre la vida y lo no vivo: «Entre las experiencias que, según Jentsch, dan origen a esa sensación de inquietud, pérdida de la orientación, angustia, que podríamos denominar unheimlich está también la de la duda acerca de la animación real que pueda tener un ser aparentemente vivo y, por el contrario, la duda a propósito de si un objeto carente de vida no esté, de algún modo, animadon ${ }^{39}$. El temor a este efecto siniestro crece a medida que avanza la tecnología y la producción de máquinas, auge que comienza en la época industrial. Así ve Ceserani la «relación entre seres vivos y autómatas: claramente relacionado con un conjunto de experimentos técnicos muy característicos del siglo XVIII (la creación de

36.- Borges, J. 1., El libro de los seres imaginarios, Emecé Editores, Barcelona, 1990, pp. 108-9.

37.- Ibidem, p. 109.

38.- Trías, E., Lo bello y lo siniestro, cit., p. 45.

39.- Ibidem, p. 22. 


\section{REFLEXIONES SOBRE LA FIGURA DEL MONSTRUO}

máquinas capaces de imitar los gestos humanos) así como con algunos experimentos teatrales (las marionctas, el cuadro vivo), pone en juego problemas de la personalidad, de la conciencia, del doble ${ }^{40}$. Y este efecto siniestro deriva de la intersección de dos realidades distintas donde notamos la pérdida de la vida en pro de la cosa. Apezteguía Bravo analiza la obra interactiva de Marcel-lí Antúnez y nos dice a este respecto: «Como dos especies incompatibles, la máquina y el cuerpo pueden crear algo, pero ese algo está siempre cercano a lo muerto» ${ }^{41}$. Si a finales del siglo XVIII apareció la investigación del tema de la fusión entre cuerpo y máquina, en el siglo XX la experimentación ha llegado a la inteligencia. El tema de la inteligencia artificial cobra auge desde la aparición de las primeras computadoras. Con gran lucidez, Safranski rescata el pensamiento de Freud sobre las "ofensas" de la Ciencia:

Fue Sigmund Freud el que finalmente compuso todo un catálogo de los espantos que la ciencia ha descubierto. Aun así, Freud se expresa en un tono moderado; no habla de lo aterrador sino de las "grandes ofensas". Menciona la "ofensa cosmológica", que alejó cósmicamente el mundo del centro; la "ofensa biológica", según la cual el hombre procede del animal y en lo esencial sigue siendo animal; y por último, la "ofensa psicológica", en virtud de la cual el hombre mismo, como ser dotado de conciencia, no es señor en su propia casa y está dominado por el inconsciente (...). Y por fin, en época reciente, se da también la ofensa por el modelo cibernético del espíritu, que cosifica el espíritu humano a manera de una calculadora digital. ${ }^{42}$

La idea de la inteligencia artificial recorre la última mitad del siglo XX y lo que llevamos de XXI. El concepto de inteligencia no ha sido definido y ya le salen derivados. Que los robots son capaces de cjecutar órdenes, previamente programados para ello, queda claro, pero parece ser que lo que sc busca es la capacidad creativa de la máquina, pero además, se llega a hablar de sentimientos artificiales. Hoy en día se especula sobre la construcción de ordenadores híbridos con componentes orgánicos. La Literatura ha tratado el tema del autómata desde distintos puntos, pero resulta curioso que el más destacado es el que nos hace comprender el "sentimiento" monstruoso de la máquina que no logra ser reconocida por el hombre. En la obra El hombre bicentenario, de Isaac Asimov, el protagonista es un robot construido con tal perfección que incluso llega a adquirir conciencia de sí mismo. Se trata de un robot talentoso, Andrew, que quiere comprar su libertad y, para conseguirlo, ha de lograr un mayor grado de humanidad, es decir, ser reconocido por los humanos como uno más de ellos. Algo similar ocurre en la película de Spielberg Inteligencia artificial (A. I. Artificial Intelligence, 2001) que trata de evocar el relato de Pinocho y, sin embargo, consigue acercarse más, en su forma expositiva, a la serie de dibujos animados Marco. Igualmente ocurre en ¿Sueñan los androides con ovejas eléctricas?, donde los seres creados artificialmente pueden alcanzar un alto grado de conciencia y llegar a sentir el deseo de ser aceptados por los seres humanos; se trata de replicantes que buscan un hueco en el universo humano, puesto que su programación es tan perfecta que su parte humanizada exige esta condición y reivindica un status social. La imagen de Dios se convierte en uno de los fundamentos que buscan estas criaturas que anhelan lo humano, añoran la creencia en un creador, en un ser supremo que justifique su existencia, y ante ellos sólo encuentran a un hombre que no los reconoce como criaturas. Esta obra nos recuerda bastante al mito del Minotauro, donde el monstruo también es hijo de la trasgresión natural, pero es una trasgresión que remite a las partes oscuras de la Naturaleza. En la novela de K. Dick, el monstruo hijo de la trasgresión lo es no gracias a las fuerzas telúricas, sino al poder científico. En ambas obras, sobre todo en la adaptación cinematográfica Blade Runner, de Ridley Scott (1982), el marco es laberíntico, oscuro y enredado. También encontramos otra coincidencia notable: el héroe (Teseo o Deckard), el que acabará con la amenaza, es ayudado por una hermana

40.- Ceserani, R., Lo fantástico, cit., p. 38.

41.- Apezteguía Bravo, M., El muevo retrato. Juegos en torno a la identidad en ocho artistas contemporáneos, Tesis doctoral de la Universidad Complutense de Madrid, 2005, p. 296.

42.- Safranski, R., El mal o el drama de la libertad, cit., p. 221. 


\section{HELENA TUR PLANELLS}

del monstruo. En el caso del Minotauro ya sabemos que se trata de Ariadna; en Blade Runner, la que traiciona a sus congéneres es otro replicante. Las semejanzas entre ambas historias revelan también su diferencia: en la época cretense, los dioses se encontraban insertos en los misterios de la Naturaleza; en el siglo XX, los dioses visten con uniforme científico. En ambos casos, posicionarnos por un momento en la mente del monstruo nos hace comprender su soledad y la falta de reconocimiento por parte de una sociedad que los desprecia. La conciencia y el problema de la identidad van nuevamente ligados en la máquina, como lo van en el monstruo y en el hombre. Asimov y K. Dick plantean desde la máquina la gran pregunta que siempre ha acompañado al hombre. Kubrick, en 2001: Una odisea del espacio (2001: A Space Odyssey, 1968) nos muestra la toma de conciencia de la computadora Hal9000. Pero en esta toma de conciencia se revela por qué el hombre teme a la máquina que crea. Hal9000 materializa la amenaza porque se rebela contra el hombre. Como Nexus y Edipo, está implícita la muerte del padre, la muerte de Dios.

Para reflexionar sobre este tema de la "humanidad" de la máquina, Safranski nos remite a Schelling: «Hablando desde el pensamiento de Schelling habríamos de argumentar que las partes de reflexividad e inteligencia que entran en la inteligencia artificial no pueden agotar en manera alguna la dimensión creadora del espíritu. Lo que puede representarse mecánica y automáticamente son, digamos, las partes automáticas y mecánicas de la inteligencia» ${ }^{43}$. Como vemos, Safranski y Schelling ven absurda la soberbia científica y la idea de una inteligencia similar a la humana. Pero el temor adquiere otras connotaciones con la aparición del universo virtual que ofrecen los ordenadores. A través de la Internet, el espacio, donde la comunicación es posible, adquiere otras características. Si Benjamin ya reflexionaba sobre el objeto artístico ante la aparición de la fotografía y el cine, con el Ciberespacio desaparece el lugar físico, y, con los $C D s$ y los vídeos, virtualmente también el temporal. Según indica Daniel Canogar, el universo virtual se completa en toda su razón de ser, en momentos en los que se produce una «arbitraria división del ser humano en cucrpo y alma y pervive en el ciberespacion ${ }^{44}$. Canogar habla de un binomio donde cuerpo real y cuerpo virtual se desacoplan uno de otro y por ello el cuerpo se convierte en «un monstruo y siniestro organismo del que hay que salir a toda costa ${ }^{45}$. En la Red de redes la identidad se fragmenta, se desintegra, se reconstruye, y ficción y realidad resultan indistinguibles. La aparición no es presencia, la comunicación no es real, lo humano se disuclve entre ceros y unos y todo posee un carácter espectral.

La existencia virtual puede darse de distintos modos ${ }^{46}$. El artista cubano afincado en Estados Unidos Raúl Cordero realizó en el año 2002 una obra que tenía como título La mujer perfecta (obra producida por el Centro de Fotografía de la Universidad de Salamanca). Se centró para ello en la idea de la belleza, la realidad y el simulacro, ilustrando su obra con cierta ironía. El artista se filmó en vídeo a sí mismo durante siete días cada mañana en su hotel de Salamanca, y en esa grabación describía los rasgos físicos de su idea de mujer perfecta. Al final de la semana se presentó con los siete vídeos ante un fisonomista de la policía científica, y le pidió que a través de esas descripciones hiciera sicte retratos-robot, que fueron confeccionados con los más modernos medios tecnológicos. La obra se exhibió conjunta, tanto las imágenes reconstruidas a través de los relatos sobre la mujer perfecta, como los propios vídeos en que la descripción se efectuaba. El resultado son siete imágenes que, debiendo responder a ideales de belleza, desasosiegan por su carácter siniestro e irreal.

43,- Ibídem, p. 63.

44.- Canogar, D., "Cuerpos virtuales, dobles reales" en Jornadas sobre arte multimedia, Barcelona, 24, 25 y 26 de abril de 1998.

45.- Ibídem.

46.- Aunque sin duda es a través de los chats de internet donde encontramos el gran paradigma. 


\section{REFLEXIONES SOBRE LA FIGURA DEL MONSTRUO}

Igualmente responden a la idea de existencia virtual las apariciones reales que encontramos en Solaris. Publicada en 1961 y escrita por Stanislav Lem, en esta obra se relata la experiencia de Kris Kelvin, quien, procedente de la Tierra, llega a una estación situada sobre la superficie de Solaris, un planeta formado por un inmenso océano viviente. En este plancta, el océano genera una influencia sobre los protagonistas (el propio Kelvin y los científicos Snaut y Sartorius), mediante la materialización de seres y pensamientos que están en la mente de los personajes. Así, aparece Harey, la esposa muerta de Kelvin, que es resucitada para volver junto a su marido. El conflicto está servido porque Kelvin y Harey pertenecen a dos planos bien distintos. Harey no es real, es simplemente una proyección mental provocada por Solaris, capaz de penetrar en la mente de Kelvin. Ella ha muerto años atrás y ahora se ha convertido en una visitante. Carlos Señor, en su libro sobre Andrei Tarkovski, el director que llevó a la pantalla esta obra en 1972 (Andrei Tarkovski, Solyaris), describe los contactos entre Kelvin y Harey como una lucha entre la voluntad de un ser imaginario que desea ser tomada por Kelvin como su esposa, «cuando ella no es más que una copia, es una imitación de la verdadera Hareys ${ }^{47}$. Harey no puede morir, en un momento de la obra ella se hace una herida en un brazo que sana espontáneamente; en otro, trata de suicidarse, pero después de morir reaparece viva. Como la fotografía, la imagen de Harey se fragmenta en sus copias. Esto provoca que Harey sea despreciada, pero su realidad es la de «un ser que sufre y piensa como él y como los demás» ${ }^{48}$. Lo interesante de esta relación es que Harcy se muestra como un personaje totalmente autónomo, con su personalidad y con voluntad propia. Pero tanto Harey y Kelvin poseen algo en común (como Nexus y el hombre bicentenario): la condición de yecto. Ninguno sabe qué debe hacer ni como ha llegado hasta allí. Harey no sabe por qué ha "resucitado" ni cómo debe relacionarse con Kelvin, pero Kelvin (cl hombre) tampoco sabe por qué ha sido creado ni cuál es su destino más radical: la vida. Harey es a la vez el producto de la voluntad de Kelvin (de su imaginario) por recuperar lo perdido y del poder que ejerce Solaris, capaz de reproducir y trasponer a la realidad imágenes mentales. En Crónicas Marcianas, de Bradbury, los marcianos tienen poderes telepáticos y la capacidad proteica de adquirir la apariencia de seres humanos. Los marcianos tambićn se metamorfosean en seres que los terrestres invasores han enterrado en la Tierra y, sólo en algunos casos, el invasor finge reconocer (por necesidad de huir del desasosiego y el dolor), en esa apariencia, a su familiar muerto.

La existencia virtual tiene un carácter monstruoso porque rompe los fundamentos de la conciencia humana $\mathrm{c}$ introduce en él una duda que cuestiona toda la estabilidad de su pensamiento. El mundo virtual nos recuerda de inmediato a Los seres especulares de Borges. Igual que la reconstrucción y la amputación del cuerpo, el ser virtual (el monstruo) exige el reconocimiento, y esta exigencia rompe a su vez el conocimiento de sí mismo de quien la sufre. Pero la existencia virtual va más allá: llega al punto de la sustitución. Afirma Baudrillard que «lo real jamás ha sido otra cosa que una forma de simulación. No cabe duda de que es posible conseguir que exista un efecto de realismo, un efecto de verdad, un efecto de objetividad, pero, en sí, lo real no existe ${ }^{49}$. Quizá ésta sea la verdad última que lleva el monstruo en sí: el recuerdo la infundamentación, la presencia de la Nada.

47.- Señor, C., Andrei Tarkovski, Ediciones JC Monteleón, Madrid, 1994, p. 124.

48.- Ibidem, p. 125.

49.- Baudrillard, J, Contraseñas, cit., p. 47. 